Neuropharmacology and analgesia

\title{
Dopaminergic and serotonergic mechanisms in the modulation of pain: In vivo studies in human brain
}

\author{
Ilkka K. Martikainen $^{\mathrm{a}, \mathrm{b}}$, Nora Hagelberg ${ }^{\mathrm{c}, \mathrm{d}}$, Satu K. Jääskeläinen ${ }^{\mathrm{e}}$, Jarmo Hietala ${ }^{\mathrm{d}, \mathrm{f}}$, \\ Antti Pertovaara ${ }^{\mathrm{a}, \mathrm{g}, *}$ \\ ${ }^{a}$ Department of Physiology, Institute of Biomedicine, University of Turku, 20520 Turku, Finland \\ ${ }^{\mathrm{b}}$ Medical Imaging Center, Department of Radiology, Tampere University Hospital, 33521 Tampere, Finland \\ ${ }^{\mathrm{c}}$ Department of Anesthesiology and Intensive Care, Turku University Central Hospital and University of Turku, 20520 Turku, Finland \\ d Turku PET Centre, Turku University Central Hospital and University of Turku, 20520 Turku, Finland \\ e Department of Clinical Neurophysiology, Turku University Central Hospital and University of Turku, 20520 Turku, Finland \\ ${ }^{\mathrm{f}}$ Department of Psychiatry, Turku University Central Hospital and University of Turku, 20520 Turku, Finland \\ ${ }^{\mathrm{g}}$ Department of Physiology, Faculty of Medicine, University of Helsinki, 00014 Helsinki, Finland
}

\section{A R T I C L E I N F O}

\section{Keywords:}

Dopamine $D_{2} / D_{3}$ receptor

Serotonin $5-\mathrm{HT}_{1 \mathrm{~A}}$ receptor

Serotonin $5-\mathrm{HT}_{2 \mathrm{~A}}$ receptor

Positron emission tomography

Pain modulation

Psychophysics

\begin{abstract}
A B S T R A C T
Here we review the literature assessing the roles of the brain dopaminergic and serotonergic systems in the modulation of pain as revealed by in vivo human studies using positron emission tomography. In healthy subjects, dopamine $\mathrm{D}_{2} / \mathrm{D}_{3}$ receptor availability particularly in the striatum and serotonin $5-\mathrm{HT}_{1 \mathrm{~A}}$ and $5-\mathrm{HT}_{2 \mathrm{~A}}$ receptor availabilities in the cortex predict the subject's response to tonic experimental pain. High availability of dopamine $\mathrm{D}_{2} / \mathrm{D}_{3}$ or serotonin $5-\mathrm{HT}_{2 \mathrm{~A}}$ receptors is associated with high pain intensity, whereas high availability of $5-\mathrm{HT}_{1 \mathrm{~A}}$ receptors associates with low pain intensity. Chronic neuropathic pain is associated with high striatal dopamine $D_{2} / D_{3}$ receptor availability, for which low endogenous dopamine tone is a plausible explanation, although a compensatory increase in striatal dopamine $\mathrm{D}_{2} / \mathrm{D}_{3}$ receptor density may also contribute. In contrast, chronic musculoskeletal pain is associated with low baseline availability of striatal dopamine $\mathrm{D}_{2} / \mathrm{D}_{3}$ receptors. In healthy subjects, brain serotonin $5-\mathrm{HT}_{1 \mathrm{~A}}$ as well as dopamine $\mathrm{D}_{2} / \mathrm{D}_{3}$ receptor availabilities associate with the subject's response criterion rather than the capacity to discriminate painful thermal stimuli suggesting that these neurotransmitter systems act mainly on non-sensory rather than sensory factors of thermally induced pain experience. Additionally, 5- $\mathrm{HT}_{1 \mathrm{~A}}$ receptor availability predicts the subject's discriminative ability but not response criterion for non-painful tactile test stimuli, while no such correlation is observed with dopamine $D_{2} / D_{3}$ receptors. These findings suggest that dopamine acting on striatal dopamine $\mathrm{D}_{2} / \mathrm{D}_{3}$ receptors and serotonin acting on cortical $5-\mathrm{HT}_{1 \mathrm{~A}}$ and $5-\mathrm{HT}_{2 \mathrm{~A}}$ receptors contribute to top-down pain regulation in humans.
\end{abstract}

\section{Introduction}

Monoamines dopamine and serotonin exert an important role in the regulation of several aspects of behavior, such as motivation, reinforcement, mood, movement and various cognitive functions. Positron emission tomography (PET) with selective radioligands for dopamine and serotonin neurotransmission has allowed in vivo studies of these neurotransmitter systems in the human brain. This review focuses on studies assessing the roles of the brain dopamine and serotonin systems in the pathophysiology and top-down control of pain as revealed by human in vivo PET studies.

\section{The brain dopaminergic system}

In the brain, two of the dopaminergic cell groups have been shown to exert significant roles in pain control in humans as well as experimental animals. Of these, substantia nigra pars compacta (also known as A9) has dopaminergic projections to the dorsal striatum (the putamen and the caudate nucleus), while the ventral tegmental area (also known as A10) has dopaminergic projections to the ventral striatum (including the nucleus accumbens) and the prefrontal cortex. Moreover, a dopaminergic cell group in the hypothalamus called A11 that provides dopaminergic innervation of the spinal cord (Tohyama and Takatsuji, 1998) has been shown to contribute to the dopaminergic control of spinal pain-relay neurons in experimental animals (e.g.,

\footnotetext{
* Correspondence to: Department of Physiology, Faculty of Medicine, University of Helsinki, POB 63, 00014 Helsinki, Finland.

E-mail address: antti.pertovaara@helsinki.fi (A. Pertovaara).
} 
Fleetwood-Walker et al., 1988; Taniguchi et al., 2011). Due to technical limitations, PET methods have not yet been used for assessing dopaminergic pain control under in vivo conditions in the human spinal cord. Therefore, control of spinal pain-relay neurons is outside the scope of this review.

Dopamine-induced functions are mediated by $\mathrm{G}$ protein-coupled receptors that are divided into two major groups. The $\mathrm{D}_{1}$ class of dopamine receptors consists of $D_{1}$ and $D_{5}$ subgroups, while the $D_{2}$ class of dopamine receptors consists of $\mathrm{D}_{2}, \mathrm{D}_{3}$ and $\mathrm{D}_{4}$ subgroups (Beaulieu and Gainetdinov, 2011). While at present there is little evidence for the role of the $\mathrm{D}_{1}$ class of dopamine receptors in pain control, there is abundant evidence from experimental animal and human studies that the striatal $D_{2}$ receptors and the (ventral striatal) $D_{3}$ receptors have key roles in mediating dopaminergic pain control in the brain (see for review, Wood, 2008). Since dopaminergic compounds and the radioligands used to assess dopamine $\mathrm{D}_{2}$ receptor availability may reflect actions on the dopamine $\mathrm{D}_{3}$ as well as dopamine $\mathrm{D}_{2}$ receptors, the term dopamine $D_{2} / D_{3}$ receptor is used in the present text. Dopamine $D_{2} / D_{3}$ receptors are expressed both postsynaptically as heteroreceptors on non-dopaminergic target cells and presynaptically as autoreceptors on dopaminergic neurons. Dopamine $\mathrm{D}_{2} / \mathrm{D}_{3}$ autoreceptors provide a negative feedback mechanism that reduces the neuronal discharge, synthesis and release of dopamine as a response to increased extracellular dopamine level (Beaulieu and Gainetdinov, 2011).

\subsection{In vivo measurement of dopamine receptor availability in the human brain}

The development of radioligands binding to dopamine $\mathrm{D}_{2} / \mathrm{D}_{3}$ receptors has allowed studying $\mathrm{D}_{2} / \mathrm{D}_{3}$ receptor availability with PET under in vivo conditions in human subjects (Farde et al., 1988). The density of dopamine $D_{2} / D_{3}$ receptors varies markedly between brain areas innervated by dopaminergic neurons (Hall et al., 1994). In a brain area with a high density of dopamine $\mathrm{D}_{2} / \mathrm{D}_{3}$ receptors, such as the striatum, e.g. $\left[{ }^{11} \mathrm{C}\right]$ raclopride has proved useful for PET studies (Hietala et al., 1994). In extrastriatal brain areas with a considerably lower density of dopamine $D_{2} / D_{3}$ receptors, $\left[{ }^{11} \mathrm{C}\right] \mathrm{FLB} 457$ has been used successfully in neurotransmitter PET studies (Lundkvist et al., 1998). In general, differences in neurotransmitter receptor availability for radioligands in PET studies could be explained by a difference in receptor density, synaptic release or level (tone) of the neurotransmitter, or receptor affinity. Earlier, it was reported that the dopamine $D_{2} / D_{3}$ receptor affinity varies only little suggesting that receptor affinity may be the least likely factor to explain a change in dopamine $D_{2} / D_{3}$ receptor availability (Farde et al., 1995; however, see the effects of dopamine $\mathrm{D}_{2}$ receptor gene polymorphism in chapter 2.5 ). On the other hand, behavioral manipulations or drugs influencing synaptic dopamine levels have been shown to change dopamine $D_{2} / D_{3}$ receptor availability (Laruelle, 2000). Thus, an acute decrease in dopamine $\mathrm{D}_{2} / \mathrm{D}_{3}$ receptor availability for a competing PET ligand can be explained by an increased dopamine neuron burst activity and release of endogenous dopamine occupying the dopamine receptors. Also potential receptor internalization can contribute to changes in receptor availability. In addition to the measurement of dopamine $\mathrm{D}_{2} / \mathrm{D}_{3}$ receptor availability, presynaptic function of dopaminergic neurons in the brain has been determined in vivo by using $6-\left[{ }^{18} \mathrm{~F}\right]$ fluorodopa, which reflects the striatal dopamine synthesis capacity.

In experimental animal studies, activation of striatal dopamine $\mathrm{D}_{2}$ / $\mathrm{D}_{3}$ receptors especially in dorsolateral putamen by intracerebral microinjection of a selective agonist has attenuated pain-related behavior, while a dopamine $D_{2} / D_{3}$ receptor antagonist has enhanced pain behavior in various types of experimental pain conditions (e.g., Ansah et al., 2007; Magnusson and Fisher, 2000; Taylor et al., 2003). This finding supports the interpretation that striatal dopamine release is a plausible explanation for the associations between pain measures and changes in striatal dopamine $D_{2} / D_{3}$ receptor availability, particularly when
Table 1

Association of healthy subjects' somatosensory responses with baseline availability of striatal dopamine $\mathrm{D}_{2} / \mathrm{D}_{3}$ receptors.

\begin{tabular}{lcl}
\hline $\begin{array}{l}\text { Somatosensory response associated with } \\
\text { high dopamine } \mathbf{D}_{\mathbf{2}} / \mathbf{D}_{\mathbf{3}} \text { receptor availability }\end{array}$ & Reference \\
\hline $\begin{array}{l}\text { Intensity of tonic experimental } \\
\text { pain }\end{array}$ & $\uparrow$ & $\begin{array}{l}\text { Hagelberg et al. (2002b), Scott } \\
\text { et al. (2006) and Wood et al. } \\
\text { (2007b) }\end{array}$ \\
$\begin{array}{l}\text { Capacity to recruit central pain } \\
\text { inhibition }\end{array}$ & $\uparrow$ & Hagelberg et al. (2002b) \\
$\begin{array}{l}\text { Heat pain threshold } \\
\text { Capacity to discriminate heat }\end{array}$ & $\leftrightarrow$ & $\begin{array}{l}\text { Pertovaara et al. (2004); } \\
\text { stimuli }\end{array}$ \\
$\begin{array}{l}\text { Criterion to classify heat stimuli } \\
\text { painful }\end{array}$ & $\downarrow$ & $\begin{array}{l}\text { Ledermann et al. (2005) } \\
\text { Pertovaara et al. (2004); }\end{array}$ \\
$\begin{array}{l}\text { Tactile detection threshold } \\
\text { Capacity to discriminate tactile } \\
\text { stimuli }\end{array}$ & $\leftrightarrow$ & $\begin{array}{l}\text { Ledermann et al. (2016) } \\
\text { Pertovaara et al. (2004); }\end{array}$ \\
$\begin{array}{l}\text { Criterion to report detection of } \\
\text { tactile stimuli }\end{array}$ & $\leftrightarrow$ & $\begin{array}{l}\text { Ledermann et al. (2016) } \\
\text { Martikainen et al. (2005) }\end{array}$ \\
\hline
\end{tabular}

$\uparrow$, increased; $\downarrow$, decreased; $\leftrightarrow$, no correlation.

dealing with treatment-induced effects in challenge-type study designs. However, differences in receptor availability in baseline conditions may also be explained by alterations in receptor expression (density) or combined effects of receptor density and affinity.

\subsection{Dopamine $D_{2} / D_{3}$ receptor availability as a predictor of the response to pain in healthy subjects}

Baseline dopamine $D_{2} / D_{3}$ receptor availability in the dorsal striatum of healthy subjects has been reported to have a negative correlation with cold pressor pain (Hagelberg et al., 2002b), heat pain (Martikainen et al., 2005; Pertovaara et al., 2004) and hypertonic saline-induced pain (Scott et al., 2006; Wood et al., 2007b): Thus, low striatal dopamine $D_{2} / D_{3}$ receptor availability compatible with high synaptic endogenous dopamine tone predicts low intensity of experimental pain (Table 1). Conditioning pain stimulation produced a contralateral heat pain threshold elevation, the magnitude of which had a positive correlation with the striatal dopamine $D_{2} / D_{3}$ receptor availability in healthy young men (Hagelberg et al., 2002b). In other words, high availability of dopamine $D_{2} / D_{3}$ receptors predicts high capacity to recruit pain inhibitory circuitry that suppresses pain at a distant test site. In these studies, the findings were lateralized and the lateralization varied with the investigated parameter (tonic pain intensity versus pain modulation capacity). Interestingly, a more recent study reported that heat pain threshold of healthy women had a positive correlation with striatal dopamine $D_{2} / D_{3}$ receptor availability (Ledermann et al., 2016). Among potential factors explaining the difference in the cited striatal findings has been proposed to be the gender of the studied subjects (Ledermann et al., 2016). Concerning extrastriatal areas, dopamine $\mathrm{D}_{2} /$ $\mathrm{D}_{3}$ receptor availability in the right medial temporal cortex was negatively correlated with cold pressor tolerance, while cold or heat pain thresholds were not associated with extrastriatal receptor availability (Hagelberg et al., 2002b; Pertovaara et al., 2004).

Traditional pain threshold is influenced by the subject's capacity to discriminate stimuli (a sensory factor in perception) and the subject's response criterion (a non-sensory factor) determining at which stimulus intensity the subject rates the stimulus as painful (Clark, 1974). The sensory and non-sensory factor in the subject's response can be dissociated using an analysis based on the signal detection theory (Swets, 1973). When the sensory and non-sensory factors in the healthy subject's response to noxious heat were analyzed separately, the capacity to 
discriminate heat stimuli failed to have any correlation with the baseline dopamine $D_{2} / D_{3}$ receptor availability in striatal or extrastriatal regions (Ledermann et al., 2016; Pertovaara et al., 2004). However, a parameter representing the subject's attitude towards pain, the response criterion, was negatively correlated with the baseline striatal dopamine $D_{2} / D_{3}$ receptor availability (Ledermann et al., 2016; Pertovaara et al., 2004). Accordingly, subjects with high availability of striatal dopamine $D_{2} / D_{3}$ receptors, presumably reflecting low extracellular endogenous dopamine tone, rate the same stimulus as more painful than subjects with low availability of striatal dopamine $\mathrm{D}_{2} / \mathrm{D}_{3}$ receptors. Together, the studies assessing heat pain sensitivity using the signal detection theory-based analyses suggest that dorsal striatal dopamine $D_{2} / D_{3}$ receptors influence non-sensory rather than sensory factors modulating the pain response of healthy subjects.

The type or modality of test stimulation may influence the role of striatal dopamine $\mathrm{D}_{2} / \mathrm{D}_{3}$ receptors in modulation of somatic sensations. Namely, mechanical hyperalgesia induced by an experimental freeze lesion in healthy subjects was not associated with baseline dopamine $\mathrm{D}_{2} / \mathrm{D}_{3}$ receptor availability in the dorsal striatum (Hagelberg et al., 2002a, 2004). Nor was the detection threshold, discriminative capacity or response criterion for innocuous mechanical stimulation correlated with baseline dopamine $\mathrm{D}_{2} / \mathrm{D}_{3}$ receptor availability (Martikainen et al., 2005).

Intramuscular infusion of hypertonic saline provides a method for measuring the effect of sustained pain stress. A study assessing the hypertonic saline-induced change of dopamine $D_{2} / D_{3}$ receptor availability in healthy subjects reported that the change of dopamine $D_{2} / D_{3}$ receptor availability in the dorsal striatum was exclusively correlated with sensory and affective pain ratings, whereas that in the ventral striatum was associated with the ratings of negative affect and fear (Scott et al., 2006). This result implies that dopamine $D_{2} / D_{3}$ receptor activation in the dorsal striatum is associated with the sensory and affective pain experience while that in the ventral striatum is associated with the emotional state in subjects exposed to a sustained pain stimulus.

\subsection{Dopamine in placebo analgesia}

The role of dopamine in placebo analgesia has been studied in various experimental paradigms. Baseline dopamine $\mathrm{D}_{2} / \mathrm{D}_{3}$ receptor availability in the dorsal striatum was not associated with the placeboinduced elevation of heat pain threshold (Martikainen et al., 2005). However, placebo administration was associated with dopamine release and dopamine $\mathrm{D}_{2} / \mathrm{D}_{3}$ receptor activation in the ventral striatum (Scott et al., 2007b, 2008). This ventral striatal dopamine system activation was correlated with expectations of analgesia and with the magnitude of placebo analgesia as well as the increase in ratings of positive affect. Further, the nucleus accumbens dopamine $D_{2} / D_{3}$ receptor activation was associated with the activation of brain $\mu$-opioid system in regions involved in pain control. Interestingly, the magnitude of placebo analgesia varied considerably among subjects, which, at least partly, could be explained by individual variability in the ventral striatal dopaminergic response (Scott et al., 2007b). A more recent PET study suggested that dopamine might contribute to attenuation of experimental pain by placebo also in the cortex, since dopamine $\mathrm{D}_{2} / \mathrm{D}_{3}$ receptor availability in the ventrolateral prefrontal cortex was lower in the placebo than control condition (Jarcho et al., 2015).

The role of the dopamine system in placebo analgesia is corroborated by studies showing the significance of genetic polymorphisms affecting the dopamine pathway on placebo analgesic response. Catechol-O-methyltransferase (COMT) val $^{158}$ met polymorphism predicted placebo analgesia in healthy humans (Yu et al., 2014) and placebo effect in patients with irritable bowel disease (Hall et al., 2012); in both studies, COMT val carriers exhibited lower placebo effect than carriers of the COMT met allele, who have increased dopamine levels in the prefrontal cortex. A PET imaging study addressed the significance of a functional single nucleotide polymorphism of the brain derived neurotrophic factor (BDNF) gene $v a l^{66}$ met on striatal dopamine $\mathrm{D}_{2} / \mathrm{D}_{3}$ receptor activation in the context of placebo (Peciña et al., 2014). In this study, BDNF $m e t^{66}$ carriers had increased baseline dopamine $\mathrm{D}_{2} / \mathrm{D}_{3}$ receptor availability suggesting chronically lower dopamine tone. The BDNF $m e t^{66}$ carriers also showed deactivation of dopamine $\mathrm{D}_{2} / \mathrm{D}_{3}$ receptors in the nucleus accumbens during placebo challenge when compared to BDNF val carriers.

Overall, current evidence indicates an important role for the dopamine system and striatal dopamine $\mathrm{D}_{2} / \mathrm{D}_{3}$ receptor activation in placebo analgesia (Peciña and Zubieta, 2015). Despite this, a few studies have challenged the view that striatal dopamine neurotransmission would be causally involved in placebo analgesia. Haloperidol, a dopamine $\mathrm{D}_{2} / \mathrm{D}_{3}$ receptor antagonist, had no effects on placebo analgesia at behavioral or neural level, as measured using functional magnetic resonance imaging (Wrobel et al., 2014). In a recent pharmacological study, haloperidol or levodopa failed to influence placebo effect in patients with neuropathic pain, although the level of expectancy was changed (Skyt et al., 2018). Importantly, these studies did not measure striatal dopamine neurotransmission directly, and it is also not known whether higher drug doses would have revealed significant placebo effects.

\subsection{Dopamine in the attenuation of pain by repetitive transcranial magnetic stimulation}

Non-invasive repetitive transcranial magnetic stimulation (rTMS) of the primary motor cortex or prefrontal cortex as well as invasive electric motor cortex stimulation have been reported to attenuate pain in experimental and clinical conditions (Maarrawi et al., 2007; Moisset et al., 2016). There is some evidence suggesting that dopamine might be among the multiple mechanisms underlying the cortical stimulationinduced analgesic effect. In an experimental animal model of neuropathy, spinal antinociception induced by motor cortex stimulation was suppressed following a block of dopamine $\mathrm{D}_{2} / \mathrm{D}_{3}$ receptors in the dorsal striatum or spinal cord, or following local anesthesia of the dopaminergic A11 cell group (Viisanen et al., 2012). These findings in an experimental animal model of neuropathy suggest that dopamine release contributes to the antinociceptive effect of motor cortex stimulation by action on dorsal striatal and spinal dopamine $D_{2} / D_{3}$ receptors. In the clinic, however, rTMS-induced supraspinal effects on pain appraisal may be more important for the pain treatment than spinal antinociception (see refs. in Moisset et al., 2016).

In healthy human subjects, dopamine $D_{2} / D_{3}$ receptor availability was decreased in the caudate nucleus and the putamen following rTMS targeting the dorsolateral prefrontal cortex (Strafella et al., 2001) or the motor cortex (Strafella et al., 2003), respectively. Moreover, rTMS of the left but not right dorsolateral prefrontal cortex has been shown to decrease dopamine $D_{2} / D_{3}$ receptor availability, indicating synaptic dopamine release, in the anterior cingulate cortex, a brain area implicated (among other functions) in pain (Cho and Strafella, 2009). These findings are in agreement with the interpretation that rTMS induces dopamine release that causes increased occupation of dopamine $\mathrm{D}_{2} / \mathrm{D}_{3}$ receptors by endogenous dopamine leading to decreased receptor availability for the radioligand. Interestingly, while rTMS of the primary motor cortex in humans influenced dopaminergic system in the dorsal striatum (Strafella et al., 2003), rTMS of the primary motor cortex in non-human primates reduced dopamine $\mathrm{D}_{2} / \mathrm{D}_{3}$ receptor availability in the ventral rather than dorsal striatum suggesting activation of meso- rather than nigrostriatal dopamine release (Ohnishi et al., 2004). Together, these findings are in line with the hypothesis that dopamine release and its action on the striatal dopamine $D_{2} / D_{3}$ receptors might contribute to the rTMS-induced behavioral effects, among which has been reported to be attenuation of pain appraisal, although not invariably (Moisset et al., 2016). On the other hand, a recent PET study (Lamusuo et al., 2017), in which expectation and 
thereby potential expectation-induced striatal dopamine release (de la Fuente-Fernández et al., 2001) was controlled, reported that rTMS of the primary somatosensory/motor cortex in healthy subjects failed to produce a significant change in striatal dopamine $D_{2} / D_{3}$ receptor availability. However, $\mu$-opioid receptor availability was reduced indicating release of endogenous opioids in various brain areas that are involved in pain processing (Lamusuo et al., 2017). These findings do not exclude potential involvement of dopamine and dopamine $\mathrm{D}_{2} / \mathrm{D}_{3}$ receptors in the early phase, since the delay from rTMS treatment to PET scanning in the cited study was close to $2 \mathrm{~h}$ (Lamusuo et al., 2017). This delay is longer than the duration of the phasic dopamine $D_{2} / D_{3}$ receptor availability change induced by a non-pharmacological manipulation (Scott et al., 2007a). Considering the existing evidence, it may thus be hypothesized that an early short-lasting activation of the dopaminergic system triggers a more prolonged activation of the $\mu$ opioidergic system (Lamusuo et al., 2017) that contributes to the rTMSinduced analgesia, similar as has been shown for invasive motor cortex stimulation (Maarrawi et al., 2007). In line with this proposal, the delay from the rTMS treatment to PET scanning was significantly shorter (minutes) in the previous studies demonstrating an rTMS-induced change of dopamine $D_{2} / D_{3}$ receptor availability (Strafella et al., 2001, 2003).

\subsection{Polymorphism of dopamine $D_{2}$ receptors influences pain and its modulation}

The finding that polymorphism of the dopamine transporter gene (DAT-1) is associated with the pain response in healthy humans supports the concept that dopamine is involved in pain regulation (Treister et al., 2009). Concerning receptors mediating pain modulation by dopamine, genetic variability of dopamine $\mathrm{D}_{2}$ receptors has been shown to influence receptor availability in PET studies. C957T polymorphism of the dopamine $\mathrm{D}_{2}$ receptor gene has been associated with striatal dopamine $D_{2} / D_{3}$ receptor availability; in baseline conditions, subjects with the C957T TT genotype have higher dopamine $\mathrm{D}_{2} / \mathrm{D}_{3}$ receptor availability and accordingly, lower endogenous dopamine tone in the striatum than those with the CT or CC genotype (Hirvonen et al., 2004, 2009). The C957T polymorphism of the dopamine $D_{2}$ receptor gene has also been shown to predict baseline sensitivity to experimental pain and the magnitude of analgesia induced by rTMS of the primary somatosensory cortex in healthy subjects (Jääskeläinen et al., 2014). Subjects with the TT genotype of the dopamine $\mathrm{D}_{2}$ receptor-coding C957T gene who presumably have the highest availability of striatal dopamine $\mathrm{D}_{2} /$ $\mathrm{D}_{3}$ receptors (Hirvonen et al., 2004, 2009) had the lowest baseline thermal pain thresholds and the strongest analgesic effect by rTMS (Jääskeläinen et al., 2014). Based on this finding, it may be hypothesized that when the proportion of subjects with the C957T TT genotype is high in the study sample, then striatal dopamine $D_{2} / D_{3}$ availability has a strong inverse correlation with baseline pain response and a strong positive correlation with the capacity to recruit pain inhibition by various types of conditioning stimulation (such as e.g. in Hagelberg et al., 2002b). The variation in the magnitude of the rTMS-induced analgesia with the dopamine $\mathrm{D}_{2}$ receptor C957T polymorphism gives further support to the proposal that dopamine acting via dopamine $\mathrm{D}_{2}$ / $D_{3}$ receptors exerts a role in therapeutic pain modulation by rTMS of the sensory-motor cortex (Jääskeläinen et al., 2014). Interestingly, $v^{158}{ }^{15}$ met polymorphism of COMT, an enzyme involved in dopamine metabolism only in extrastriatal regions (Yavich et al., 2007), was not associated with the rTMS-induced increase of thermal pain thresholds suggesting specific involvement of striatal rather than extrastriatal dopamine in the rTMS-induced pain modulation (Jääskeläinen et al., 2014).

\subsection{Dopamine in chronic pain conditions that are primarily of neural origin}

\subsubsection{Burning mouth syndrome and atypical facial pain}

Burning mouth syndrome is an orofacial neuropathic pain condition affecting peripheral and central nervous system (Jääskeläinen, 2018). Several lines of evidence indicate dopaminergic hypofunction of the nigrostriatal system in the burning mouth syndrome. This is shown by the findings that $6-\left[{ }^{18} \mathrm{~F}\right]$ fluorodopa uptake was reduced (Jääskeläinen et al., 2001) and dopamine $D_{2} / D_{3}$ receptor availability increased (Hagelberg et al., 2003b) in the putamen of burning mouth patients. These PET findings are similar to those reported in early Parkinson's disease. Additionally, blink reflex habituation that is controlled by nigrostriatal dopamine system (Basso et al., 1993) is frequently deficient in burning mouth symptom patients (Forssell et al., 2002; Jääskeläinen et al., 1997). In another chronic orofacial pain condition, atypical facial pain, dopamine $\mathrm{D}_{2} / \mathrm{D}_{3}$ receptor availability in the putamen was increased indicating dopaminergic disorder in the basal ganglia (Hagelberg et al., 2003a). Unlike in the burning mouth syndrome (Jääskeläinen et al., 2001), 6- $\left[{ }^{18} \mathrm{~F}\right]$ fluorodopa uptake was not significantly decreased in patients with atypical facial pain (Hagelberg et al., 2003b) suggesting that there may be some differences in the dopamine-related pathophysiological mechanisms between these two chronic orofacial pain conditions. Further evidence for the role of dopamine in chronic orofacial pain syndromes is the finding that the prevalence of the C957T TT genotype that is associated with increased availability of dopamine $D_{2} / D_{3}$ receptors and low striatal dopamine tone (Hirvonen et al., 2004, 2009) was significantly higher in patients with orofacial neuropathic pain than in controls $(50 \%$ versus $27 \%$; Jääskeläinen et al., 2014). This is in line with the proposal that the dopamine system exerts an important role in the pathogenesis of orofacial neuropathic pain (Jääskeläinen, 2012; Jääskeläinen and Woda, 2017).

\subsubsection{Central pain in Parkinson's disease}

While Parkinson's disease is traditionally considered a movement disorder, it is accompanied by various cognitive, emotional and sensory symptoms. Among frequently occurring sensory symptoms in Parkinson's disease is pain that can be characterized either central neuropathic or nociceptive type of pain (Conte et al., 2013; Zhu et al., 2016). It is well established that impairment of the nigrostriatal dopaminergic system is a pathognomonic finding of the Parkinson's disease that can be demonstrated under in vivo conditions using PET (Niccolini et al., 2014). The impaired dopamine system function is accompanied by increased striatal availability of dopamine $D_{2} / D_{3}$ receptors (Niccolini et al., 2014). This together with the finding that at least some pain symptoms in Parkinson's disease may be attenuated by dopaminergic drugs, such as levodopa, suggest that a deficit in the dopaminergic system is among mechanisms contributing to central pain in Parkinson's disease (Zhu et al., 2016).

\subsubsection{Pain in restless legs syndrome}

Restless legs syndrome, as Parkinson's disease, is primarily considered a movement disorder characterized by unpleasant sensations in the legs and accompanied by sensory alterations such as pin prick hyperalgesia, tactile hypoesthesia and dysesthesia to innocuous cold (Stiasny-Kolster et al., 2013). PET studies have revealed abnormalities in the dopaminergic system. For example, dopamine $D_{2} / D_{3}$ receptor availability in a sample of restless legs syndrome patients was increased both in extrastriatal and striatal areas. The most prominent increase was observed in the ventral striatum (Cervenka et al., 2006). Presynaptic hypofunction of the nigrostriatal dopaminergic system has also been reported in restless legs patients (Ruottinen et al., 2000). Treatment with L-Dopa significantly alleviated sensory symptoms in the restless legs syndrome patients supporting the hypothesis that dopaminergic impairment may at least partly explain hyperalgesia and dysesthesia in these patients (Stiasny-Kolster et al., 2013). 


\subsubsection{Migraine}

DaSilva et al. (2017) studied with PET scanning the potential role of dopamine in migraine. They found that the baseline striatal dopamine $D_{2} / D_{3}$ receptor availability of migraine patients in the interictal phase (when there is no headache attack) did not differ from that in healthy controls. During the headache attack, striatal dopamine $\mathrm{D}_{2} / \mathrm{D}_{3}$ receptor availability was significantly higher than in the interictal phase or in healthy controls. When the trigeminal area of migraine patients was exposed to experimental heat stimulation-induced challenge that elicited allodynia (unpleasantness) during the migraine attack, dopamine $D_{2} / D_{3}$ receptor availability was reduced both in the striatum and the insula, a cortical structure involved in pain-processing. Experimental heat-induced challenge reduced dopamine $\mathrm{D}_{2} / \mathrm{D}_{3}$ receptor availability also in healthy controls. These findings suggest that migraine patients have reduced striatal dopamine release during the headache attack, which in turn leads to malfunctioning of endogenous pain inhibition. Still, migraine patients can increase dopamine release during the headache attack, when confronted with relevant stimulation. Together, these findings suggest that an imbalance in the dopamine system during the headache attack may contribute to pain and discomfort in migraine (DaSilva et al., 2017).

\subsection{Dopamine in chronic musculoskeletal pain conditions}

\subsubsection{Fibromyalgia}

Fibromyalgia is a chronic soft tissue pain condition present particularly in middle-aged women (Russell and Bieber, 2006). In a study assessing the role of the striatal dopaminergic system in fibromyalgia, it was found that baseline availability of dopamine $\mathrm{D}_{2} / \mathrm{D}_{3}$ receptors in the ventral as well as dorsal striatum was lower in fibromyalgia patients than in controls (Wood et al., 2007b). Moreover, the hypertonic salineinduced decrease of striatal dopamine $\mathrm{D}_{2} / \mathrm{D}_{3}$ receptor availability was reduced in fibromyalgia patients and, unlike in healthy controls, it did not correlate with the magnitude of hypertonic saline-induced pain (Wood et al., 2007b). Uptake of $6-\left[{ }^{18} \mathrm{~F}\right]$ fluorodopa, an index of presynaptic dopaminergic activity, was reduced in the ventral tegmental area, substantia nigra, thalamus, and anterior cingulate and insular cortices in fibromyalgia patients (Wood et al., 2007a). This finding gives support to the proposal that abnormal dopamine system function contributes to the pathophysiology of fibromyalgia. A more recent study extended the finding that fibromyalgia is associated with a decrease of striatal dopamine $D_{2} / D_{3}$ receptor availability by showing that the decrease of receptor availability was significantly stronger in fibromyalgia patients with comorbid depression (Ledermann et al., 2016). Another recent study further elaborated these findings by showing that dopamine $D_{2} / D_{3}$ receptor availability in fibromyalgia patients was decreased in extrastriatal areas, particularly in brain areas involved in emotions and stress regulation (Albrecht et al., 2016). Furthermore, the dopamine $D_{2} / D_{3}$ receptor availability also in extrastriatal areas was negatively correlated with the magnitude of ongoing fibromyalgia pain and with that of pressure-induced experimental pain
(Albrecht et al., 2016). Together, these in vivo PET studies support the interpretation that abnormal function of the dopaminergic system contributes to pain in fibromyalgia.

\subsubsection{Chronic back pain}

In chronic back pain patients, the baseline dopamine $\mathrm{D}_{2} / \mathrm{D}_{3}$ receptor availability and also the tonic experimental pain challenge-induced dopamine $D_{2} / D_{3}$ receptor activation, as revealed by the change in dopamine $\mathrm{D}_{2} / \mathrm{D}_{3}$ receptor availability, were decreased in the right ventral striatum when compared with healthy controls (Martikainen et al., 2015). Baseline dopamine $D_{2} / D_{3}$ receptor availability in the ventral striatum was positively correlated with baseline availability of $\mu$-opioid receptors, and negatively with pain challenge-induced $\mu$-opioid receptor activation in the amygdala. The decreased availability of ventral striatal dopamine $D_{2} / D_{3}$ receptors in chronic back pain patients was associated with high positive affect and low pain sensitivity. This finding suggests that the changes in the striatal dopaminergic system as well as those in the amygdaloid opioidergic system may represent mechanisms helping to cope with chronic pain and accompanying stress (Martikainen et al., 2015).

\subsection{In vivo dopamine findings in pain conditions of neural versus musculoskeletal origin}

Abnormal function of the dopaminergic system has varied with the type of the chronic pain condition. Pain conditions that are primarily of neural origin, such as chronic neuropathic orofacial pain (Hagelberg et al., 2003a, b), migraine in the ictal phase (DaSilva et al., 2017), central pain in Parkinson's disease (Niccolini et al., 2014), and pain in restless legs syndrome (Cervenka et al., 2006) have been associated with an increased baseline availability of striatal dopamine $D_{2} / D_{3}$ receptors. In contrast, pain conditions that are primarily of musculoskeletal origin, such as fibromyalgia (Ledermann et al., 2016; Wood et al., 2007b) or chronic back pain (Martikainen et al., 2015) associated with a decreased baseline availability of striatal dopamine $D_{2} / D_{3}$ receptors. In chronic pain of primarily musculoskeletal origin, also the capacity to increase striatal dopamine release is decreased (Martikainen et al., 2015; Wood et al., 2007b), unlike in migraine (DaSilva et al., 2017). Presynaptic dopamine level has been reduced independent whether chronic pain is due to a neural or musculoskeletal disorder, although it has been only little studied (Table 2).

It remains to be studied whether the increased striatal dopamine $\mathrm{D}_{2} / \mathrm{D}_{3}$ receptor availability in neuropathic pain conditions reflects endogenously low dopamine tone in the striatum or is predominantly due to compensatory increase in receptor density caused by the reduction in the endogenous dopaminergic tone. Moreover, it remains to be studied whether the decreased availability of striatal dopamine $D_{2} / D_{3}$ receptors in pain conditions of musculoskeletal origin is related to increased dopamine release, reduced dopamine $\mathrm{D}_{2} / \mathrm{D}_{3}$ receptor density, or both.

Table 2

Striatal dopamine assessed in vivo in clinical pain conditions.

\begin{tabular}{|c|c|c|c|}
\hline Clinical pain condition & DA $D_{2} / D_{3} R$ availability in baseline & Pain challenge-induced DA release & Presynaptic DA tone \\
\hline \multicolumn{4}{|l|}{ NEUROPATHIES } \\
\hline Burning mouth & $\uparrow$ Hagelberg et al. (2003a) & & $\downarrow$ Jääskeläinen et al. (2001) \\
\hline Atypical facial pain & $\uparrow$ Hagelberg et al. (2003b) & & $\leftrightarrow$ Hagelberg et al. (2003b) \\
\hline Migraine (ictal phase) & $\uparrow$ DaSilva et al. (2017) & $\leftrightarrow$ DaSilva et al. (2017) & \\
\hline Parkinson's & $\uparrow$ Niccolini et al. (2014) & & $\downarrow$ Niccolini et al. (2014) \\
\hline Restless legs & $\uparrow$ Cervenka et al. (2006) & & $\downarrow$ Ruottinen et al. (2000) \\
\hline \multicolumn{4}{|l|}{ MUSCULOSCELETAL } \\
\hline \multirow[t]{2}{*}{ Fibromyalgia } & $\downarrow$ Wood et al. (2007b); & $\downarrow$ Wood et al. (2007b); & $\downarrow$ Wood et al. (2007a) \\
\hline & Ledermann et al. (2016) & Ledermann et al. (2016) & \\
\hline Chronic back pain & $\downarrow$ Martikainen et al. (2015) & $\downarrow$ Martikainen et al. (2015) & \\
\hline
\end{tabular}

DA, dopamine; R, receptor; $\uparrow$, increased; $\downarrow$, decreased; $\leftrightarrow$, not changed. 


\section{The brain serotonergic system}

Serotonin pathways in the brain predominantly originate in the raphe nuclei that are located in the midline from the medulla to the midbrain. Of these, descending projections of the raphe magnus provide the main serotonergic innervation of the spinal cord, whereas the midbrain dorsal raphe nucleus provides ascending serotonergic innervation e.g. to the cerebral cortex (Tohyama and Takatsuji, 1998). There are multiple types of serotonin receptors that may contribute to regulation of various aspects of behavior, including pain (Bardin, 2011). There are very few in vivo human PET studies addressing the role of specific 5-HT receptors in pain. Among the studied 5-HT receptors is the serotonin $5-\mathrm{HT}_{1 \mathrm{~A}}$ receptor that is implicated in mood disorders (anxiety, depression), cognition, and modulation of pain (Lacivita et al., 2012). The G-protein-coupled 5- $\mathrm{HT}_{1 \mathrm{~A}}$ receptor is the predominant autoinhibitory receptor on serotonergic raphe nuclei (Bjornvatn et al., 1998; Rogawski and Aghajanian, 1981), but it is also widely distributed as a heteroreceptor in various brain regions innervated by efferent projections of the serotonergic raphe neurons (Savitz et al., 2009). Another 5-HT receptor type, the role of which in pain has been studied using $\mathrm{PET}$ in humans, is the $5-\mathrm{HT}_{2 \mathrm{~A}}$ receptor that is also G protein-coupled and involved in the control of mood and cognition as well as pain (Zhang and Stackman, 2015). Additionally, the role of serotonin in pain has been studied using PET imaging of serotonin transporters or synthesis in the human brain.

Experimental animal studies, most of which have focused on the spinal level that is beyond the focus of this review, have demonstrated that serotonin has a complex role in the control of pain that may vary from pro- to antinociception, depending among other things on the type of 5-HT receptor mediating the response, the neural structure, and the pathophysiological condition (Millan, 2002). Concerning the brain 5$\mathrm{HT}$ receptor types studied with PET in human pain control, the 5- $\mathrm{HT}_{2 \mathrm{~A}}$ receptor has been reported to have pronociceptive actions in the spinal dorsal horn of experimental animals (Millan, 2002), whereas the spinal $5-\mathrm{HT}_{1 \mathrm{~A}}$ receptor has most commonly been reported to promote antinociception (Colpaert, 2006). However, activation of medullary 5-HT $1 \mathrm{~A}$ autoreceptors has had an opposite effect, reduction of descending serotonergic antinociception (Mico et al., 2006; Wei and Pertovaara, 2006).

\subsection{In vivo measurement of 5-HT receptor availability or 5-HT transport and synthesis}

WAY-100635 is a silent antagonist of the 5- $\mathrm{HT}_{1 \mathrm{~A}}$ receptor with high selectivity and affinity (Forster et al., 1995). Its isotope, [carbonyl- ${ }^{11} \mathrm{C}$ ] WAY-100635, provides a tool for PET imaging of $5-\mathrm{HT}_{1 \mathrm{~A}}$ receptor availability in the brain (Pike et al., 1996). $\left[{ }^{18} \mathrm{~F}\right]$ Altanserin has been used for PET imaging of 5- $\mathrm{HT}_{2 \mathrm{~A}}$ receptor availability (Pinborg et al., 2003), while $\left[{ }^{11} \mathrm{C}\right] 3$-amino-4-(2-dimethylaminomethylphenylsulfanyl)benzonitrile has been used to measure brain serotonin transporter availability (Kupers et al., 2011) and $\alpha-\left[{ }^{11} \mathrm{C}\right]$ methyl-L-tryptophan has been used to study 5-HT synthesis in vivo in the human brain (e.g., Sakai et al., 2008).

\subsection{The brain serotonin $5-H T_{1 A}$ receptor availability as a predictor of the response to pain in healthy subjects}

So far, there are two studies assessing the association of pain modulation with the brain $5-\mathrm{HT}_{1 \mathrm{~A}}$ receptor availability in healthy human subjects (Table 3). The first one of them (Martikainen et al., 2007) reported that the intensity of cold pressor pain (i.e., the sensorydiscriminative component of pain sensation) was inversely correlated with the baseline $5-\mathrm{HT}_{1 \mathrm{~A}}$ receptor availability in multiple brain areas. These included the prefrontal and cingulate cortices, insula, amygdala and the dorsal raphe nucleus. However, unpleasantness of cold pressor pain (i.e., the affective-motivational component of pain sensation) was
Table 3

Association of healthy subjects' responses with baseline availability of the brain serotonin $5-\mathrm{HT}_{1 \mathrm{~A}}$ or $5-\mathrm{HT}_{2 \mathrm{~A}}$ receptors. (Data from selected brain areas; see for more details in the text).

\begin{tabular}{|c|c|c|}
\hline \multicolumn{2}{|c|}{$\begin{array}{l}\text { Response associated with high } 5-\mathrm{HT}_{1 \mathrm{~A}} \text { receptor } \\
\text { availability }\end{array}$} & Reference \\
\hline Intensity of tonic experimental pain & $\downarrow$ & Martikainen et al. (2007) \\
\hline Capacity to recruit central pain inhibition & $\uparrow$ & Martikainen et al. (2007) \\
\hline $\begin{array}{l}\text { Capacity to recruit innocuous sympathetic } \\
\text { reflex }\end{array}$ & $\uparrow$ & Martikainen et al. (2007) \\
\hline Capacity to discriminate heat stimuli & $\leftrightarrow$ & Martikainen et al. (2009) \\
\hline Criterion to classify heat stimuli painful & $\downarrow$ & Martikainen et al. (2009) \\
\hline Capacity to discriminate tactile stimuli & $\downarrow$ & Martikainen et al. (2009) \\
\hline $\begin{array}{l}\text { Criterion to report detection of tactile } \\
\text { stimuli }\end{array}$ & $\leftrightarrow$ & Martikainen et al. (2009) \\
\hline \multicolumn{3}{|c|}{ Response associated with high $5-\mathrm{HT}_{2 \mathrm{~A}}$ receptor availability } \\
\hline Intensity of tonic experimental pain & $\uparrow$ & Kupers et al. (2009) \\
\hline
\end{tabular}

$\uparrow$, increased; $\downarrow$, decreased; $\leftrightarrow$, no correlation.

not correlated with $5-\mathrm{HT}_{1 \mathrm{~A}}$ receptor availability in any of the studied brain regions. The capacity to recruit pain inhibition by conditioning noxious peripheral stimulation was positively correlated with the 5$\mathrm{HT}_{1 \mathrm{~A}}$ receptor availability in the medial prefrontal cortex and amygdala. Furthermore, the magnitude of sympathetic activation induced by a non-painful Valsalva maneuver was positively correlated with the 5$\mathrm{HT}_{1 \mathrm{~A}}$ receptor availability in the anterior insula and ventral part of the anterior cingulate cortex. Together, these results suggest that subjects with high baseline availability of the brain $5-\mathrm{HT}_{1 \mathrm{~A}}$ receptors rate experimentally induced pain with low scores and they have high capacity to recruit central pain inhibition and high capacity to recruit an innocuous sympathetic reflex (Martikainen et al., 2007). Since the negative correlation of pain intensity with $5-\mathrm{HT}_{1 \mathrm{~A}}$ receptor availability was observed in multiple brain regions, including also areas that are not known to be involved in pain processing, it is possible that the correlation reflected some general behavioral effect such as personality traits and reaction styles (Hirvonen et al., 2015) rather than specific modulation of pain processing (Martikainen et al., 2007).

The second study on the role of the brain $5-\mathrm{HT}_{1 \mathrm{~A}}$ receptors in pain control (Martikainen et al., 2009) addressed the question on the specificity of the correlations described in the first study (Martikainen et al., 2007). This was done by applying the signal detection theorybased analysis (Swets, 1973) to assess separately correlations of baseline receptor availability with the subject's sensory-discriminative capacity (sensory factor) and response criterion (nonsensory factor) in a heat pain assay and in a tactile detection assay (Martikainen et al., 2009). The results indicated that the subject's capacity to discriminate painful heat stimuli (sensory factor) was not correlated with $5-\mathrm{HT}_{1 \mathrm{~A}}$ receptor availability in any of the studied brain regions, whereas the response criterion (nonsensory factor) for heat pain was negatively correlated with $5-\mathrm{HT}_{1 \mathrm{~A}}$ receptor availability in the dorsal raphe, the posterior cingulate and orbitofrontal cortices, and the middle temporal gyrus. In contrast, the response criterion for innocuous touch was not correlated with $5-\mathrm{HT}_{1 \mathrm{~A}}$ receptor availability in any brain region, whereas the subject's capacity to discriminate touch was inversely associated with $5-\mathrm{HT}_{1 \mathrm{~A}}$ receptor availability in the cingulate and medial prefrontal cortices, and the inferior temporal gyrus (Martikainen et al., 2009). Together, these results are in line with the hypothesis that the brain $5-\mathrm{HT}_{1 \mathrm{~A}}$ receptors have a general behavioral effect that influences attitude towards pain rather than a specific modulatory action on sensory processing of pain.

The finding that the availability of cortical $5-\mathrm{HT}_{1 \mathrm{~A}}$ receptors correlates with sensory discrimination of touch was unexpected. Interestingly, it has been shown that navigated transcranial magnetic stimulation of a fiber tract connecting prefrontal cortex with the primary somatosensory cortex attenuates the amplitude of touch-evoked cortical responses (Hannula et al., 2010) and discrimination of tactile 
stimuli (Gogulski et al., 2015). Thus, it may be speculated that cortical $5-\mathrm{HT}_{1 \mathrm{~A}}$ receptors influenced the function of the fiber tract mediating the top-down control of the primary somatosensory cortex by the prefrontal cortex, and thereby had a selective action on sensory-discriminative processing of tactile signals at cortical level.

Since acute manipulations of the synaptic concentration of endogenous 5 -HT have had only a minimal effect on $5-\mathrm{HT}_{1 \mathrm{~A}}$ receptor availability in humans (Rabiner et al., 2002), the above described receptor availability results are likely to reflect $5-\mathrm{HT}_{1 \mathrm{~A}}$ receptor density rather than 5-HT release, although a potential contribution of receptor affinity may not be excluded.

\subsection{The brain serotonin $5-H T_{2 A}$ receptor availability as a predictor of the response to pain in healthy subjects}

The association of brain $5-\mathrm{HT}_{2 \mathrm{~A}}$ receptor availability with pain response in healthy subjects has been assessed in one study (Kupers et al., 2009). The $5-\mathrm{HT}_{2 \mathrm{~A}}$ receptor availability had a positive correlation with the intensity of pain induced by long- but not short-lasting heat stimulation in primary sensory-motor, posterior cingulate, orbitofrontal and medial inferior frontal cortices (Table 3). Pain threshold and tolerance were not correlated with $5-\mathrm{HT}_{2 \mathrm{~A}}$ receptor availability. Since tonic heat pain intensity was correlated predominantly with $5-\mathrm{HT}_{2 \mathrm{~A}}$ receptor availability in brain regions involved in cognitive and affective functions rather than processing of pain, the authors proposed that the brain $5-\mathrm{HT}_{2 \mathrm{~A}}$ receptor has a role in cognitive evaluation and emotional processing of pain (Kupers et al., 2009). The authors also pointed out that unlike the pre- and postsynaptically located inhibitory $5-\mathrm{HT}_{1 \mathrm{~A}}$ receptor, the $5 \mathrm{HT}_{2 \mathrm{~A}}$ receptor is excitatory and located only postsynaptically, which possibly explains why the correlation of tonic pain intensity with $5-\mathrm{HT}_{1 \mathrm{~A}}$ receptor availability was negative (Martikainen et al., 2007) while that with $5-\mathrm{HT}_{2 \mathrm{~A}}$ receptor availability was positive (Kupers et al., 2009).

\subsection{Serotonin transporter availability in the brain as a predictor of pain}

Serotonin transporter is a protein that transports serotonin from the synaptic cleft back to the presynaptic serotonergic terminal, thereby terminating the transmission and allowing recycling of the neurotransmitter. In healthy subjects, high serotonin transporter availability in the hypothalamus was associated with low perceived intensity of tonic heat pain (Kupers et al., 2011). Also heat pain tolerance but not the intensity of pain induced by brief, phasic stimuli was correlated with serotonin transporter availability in the hypothalamus (Kupers et al., 2011). The association of serotonin transporter availability in the hypothalamus with tonic pain intensity in healthy subjects may reflect serotonergic modulation of the pain-induced autonomic response and feedback control by the hypothalamus.

Tominaga et al. (2015) assessed serotonin transporter availability in patients with functional dyspepsia. They found that serotonin transporter availability was higher in the midbrain and thalamus of functional dyspepsia patients than controls. Moreover, serotonin transporter availability in the midbrain and thalamus correlated with abdominal pain in the patients. Together these findings suggest that serotonin in the midbrain and the thalamus exerts a role in abdominal symptoms, including pain of functional dyspepsia patients.

\subsection{Brain serotonin synthesis in painful clinical conditions}

In vivo PET imaging of brain serotonin synthesis indicated increased synthesis widely in the brain during an acute migraine attack. Treatment with sumatriptan, a $5-\mathrm{HT}_{1}$ receptor agonist, promptly decreased brain serotonin synthesis and this was accompanied by attenuation of migraine pain (Sakai et al., 2008). Brain serotonin synthesis was lowest in the interictal phase. These findings suggest that abnormality in serotonin synthesis has a role in the pathogenesis of migraine and that an effective treatment of migraine attack may be based on negative feedback regulation of serotonin synthesis by a $5-\mathrm{HT}_{1}$ receptor agonist.

In female patients with irritable bowel syndrome serotonin synthesis in the right medial temporal gyrus was greater than in healthy controls suggesting that brain serotonin synthesis may also be related to visceral pain processing (Nakai et al., 2003). However, in male patients no such difference was found.

\section{Conclusions}

The results of in vivo brain imaging studies cited in the present review suggest that dopamine acting on dopamine $\mathrm{D}_{2} / \mathrm{D}_{3}$ receptors and serotonin acting on $5-\mathrm{HT}_{1 \mathrm{~A}}$ and $5-\mathrm{HT}_{2 \mathrm{~A}}$ receptors contribute to modulation of pain. These modulatory effects, however, may reflect action on non-sensory mechanisms, such as attention and gating of painful stimuli as well as subjective attitude towards pain, rather than a selective action on sensory-discriminative processing of pain signals.

Looped circuitries connecting the cortex and the striatum are involved in assessing competing priorities when choosing the appropriate behavioral response and tone when exposed to various environmental challenges (McHaffie et al., 2005). Concerning the cited human studies on striatal dopamine $\mathrm{D}_{2} / \mathrm{D}_{3}$ receptors and cortical serotonin receptors, it would be interesting to know whether these neurotransmitter systems contribute to pain regulation independent of each other or whether they have a coordinated interaction in the corticostriatal circuitry. In vivo imaging of these different receptors in the same subjects would allow determining whether e.g. an increased intensity of tonic experimental pain is associated with high availability of striatal dopamine $\mathrm{D}_{2}$ / $\mathrm{D}_{3}$ receptors, low availability of cortical $5-\mathrm{HT}_{1 \mathrm{~A}}$ receptors and high availability of cortical $5-\mathrm{HT}_{2 \mathrm{~A}}$ receptors, as expected if they act in concert in the corticostriatal circuitry (Hagelberg et al., 2002b; Kupers et al., 2009; Martikainen et al., 2007). Modulation of pain by the dopaminergic or serotonergic pathways or their interaction in man is also an interesting area for drug development aiming at an improved pharmacological treatment of pain.

\section{Acknowledgements}

The original experiments of the authors were financially supported by the Academy of Finland $(106804,111699,137795,315043)$ and the Sigrid Jusélius Foundation, Helsinki, Finland.

\section{References}

Albrecht, D.S., MacKie, P.J., Kareken, D.A., Hutchins, G.D., Chumin, E.J., Christian, B.T., Yoder, K.K., 2016. Differential dopamine function in fibromyalgia. Brain Imaging Behav. 10, 829-839.

Ansah, O.B., Leite-Almeida, H., Wei, H., Pertovaara, A., 2007. Striatal dopamine $\mathrm{D}_{2}$ receptors attenuate neuropathic hypersensitivity in the rat. Exp. Neurol. 205, 536-546.

Bardin, L., 2011. The complex role of serotonin and 5-HT receptors in chronic pain. Behav. Pharmacol. 22, 390-404.

Basso, M.A., Strecker, R.E., Evinger, C., 1993. Midbrain 6-hydroxydopamine lesions modulate blink reflex excitability. Exp. Brain Res. 94, 88-96.

Beaulieu, J.M., Gainetdinov, R.R., 2011. The physiology, signaling, and pharmacology of dopamine receptors. Pharmacol. Rev. 63, 182-217.

Bjornvatn, B., Fornal, C.A., Martin, F.J., Metzler, C.W., Jacobs, B.L., 1998. The 5-HT $\mathrm{HA}_{1 \mathrm{~A}}$ receptor antagonist $\mathrm{p}$-MPPI blocks 5 - $\mathrm{HT}_{1 \mathrm{~A}}$ autoreceptors and increases dorsal raphe unit activity in awake cats. Eur. J. Pharmacol. 356, 167-178.

Cervenka, S., Pålhagen, S.E., Comley, R.A., Panagiotidis, G., Cselényi, Z., Matthews, J.C., Lai, R.Y., Halldin, C., Farde, L., 2006. Support for dopaminergic hypoactivity in restless legs syndrome: a PET study on D2-receptor binding. Brain 129, 2017-2028.

Cho, S.S., Strafella, A.P., 2009. rTMS of the left dorsolateral prefrontal cortex modulates dopamine release in the ipsilateral anterior cingulate cortex and orbitofrontal cortex. PLoS One 4, e6725.

Clark, W.C., 1974. Pain sensitivity and the report of pain: an introduction to sensory decision theory. Anesthesiology 40, 272-287.

Colpaert, F.C., 2006. 5-HT 1 A receptor activation: new molecular and neuroadaptive mechanisms of pain relief. Curr. Opin. Investig. Drugs 7, 40-47.

Conte, A., Khan, N., Defazio, G., Rothwell, J.C., Berardelli, A., 2013. Pathophysiology of somatosensory abnormalities in Parkinson disease. Nat. Rev. Neurol. 9, 687-697.

DaSilva, A.F., Nascimento, T.D., Jassar, H., Heffernan, J., Toback, R.L., Lucas, S., 
DosSantos, M.F., Bellile, E.L., Boonstra, P.S., Taylor, J.M.G., Casey, K.L., Koeppe, R.A., Smith, Y.R., Zubieta, J.K., 2017. Dopamine D2/D3 imbalance during migraine attack and allodynia in vivo. Neurology 88, 1634-1641.

Farde, L., Pauli, S., Hall, H., Eriksson, L., Halldin, C., Högberg, T., Nilsson, L., Sjögren, I., Stone-Elander, S., 1988. Stereoselective binding of ${ }^{11} \mathrm{C}$-raclopride in living human brain-a search for extrastriatal central $\mathrm{D}_{2}$-dopamine receptors by PET. Psychopharmacology (Berl.) 94, 471-478.

Farde, L., Hall, H., Pauli, S., Halldin, C., 1995. Variability in $\mathrm{D}_{2}$-dopamine receptor density and affinity: a PET study with $\left[{ }^{11} \mathrm{C}\right]$ raclopride in man. Synapse 20, 200-208.

Fleetwood-Walker, S.M., Hope, P.J., Mitchell, R., 1988. Antinociceptive actions of descending dopaminergic tracts on cat and rat dorsal horn somatosensory neurones. J. Physiol. 399, 335-348.

Forssell, H., Jääskeläinen, S., Tenovuo, O., Hinkka, S., 2002. Sensory dysfunction in burning mouth syndrome. Pain 99, 41-47.

Forster, E.A., Cliffe, I.A., Bill, D.J., Dover, G.M., Jones, D., Reilly, Y., Fletcher, A., 1995. A pharmacological profile of the selective silent $5-\mathrm{HT}_{1 \mathrm{~A}}$ receptor antagonist, WAY100635. Eur. J. Pharmacol. 281, 81-88.

de la Fuente-Fernández, R., Ruth, T.J., Sossi, V., Schulzer, M., Calne, D.B., Stoessl, A.J., 2001. Expectation and dopamine release: mechanism of the placebo effect in Parkinson's disease. Science 293, 1164-1166.

Gogulski, J., Boldt, R., Savolainen, P., Guzmán-López, J., Carlson, S., Pertovaara, A., 2015. A segregated neural pathway for prefrontal top-down control of tactile discrimination. Cereb. Cortex 25, 161-166.

Hagelberg, N., Kajander, J.K., Någren, K., Hinkka, S., Hietala, J., Scheinin, H., 2002a. Mureceptor agonism with alfentanil increases striatal dopamine $\mathrm{D}_{2}$ receptor binding in man. Synapse 45, 25-30.

Hagelberg, N., Martikainen, I.K., Mansikka, H., Hinkka, S., Någren, K., Hietala, J., Scheinin, H., Pertovaara, A., 2002b. Dopamine $\mathrm{D}_{2}$ receptor binding in the human brain is associated with the response to painful stimulation and pain modulatory capacity. Pain 99, 273-279.

Hagelberg, N., Forssell, H., Aalto, S., Rinne, J.O., Scheinin, H., Taiminen, T., Någren, K., Eskola, O., Jääskeläinen, S.K., 2003a. Altered dopamine $\mathrm{D}_{2}$ receptor binding in atypical facial pain. Pain 106, 43-48.

Hagelberg, N., Forssell, H., Rinne, J.O., Scheinin, H., Taiminen, T., Aalto, S., Luutonen, S., Någren, K., Jääskeläinen, S., 2003b. Striatal dopamine $D_{1}$ and $D_{2}$ receptors in burning mouth syndrome. Pain 101, 149-154.

Hagelberg, N., Jääskeläinen, S.K., Martikainen, I.K., Mansikka, H., Forssell, H., Scheinin, H., Hietala, J., Pertovaara, A., 2004. Striatal dopamine $\mathrm{D}_{2}$ receptors in modulation of pain in humans: a review. Eur. J. Pharmacol. 500, 187-192.

Hall, H., Sedvall, G., Magnusson, O., Kopp, J., Halldin, C., Farde, L., 1994. Distribution of $\mathrm{D}_{1}$ - and $\mathrm{D}_{2}$-dopamine receptors, and dopamine and its metabolites in the human brain. Neuropsychopharmacology 11, 245-256.

Hall, K.T., Lembo, A.J., Kirsch, I., Ziogas, D.C., Douaiher, J., Jensen, K.B., Conboy, L.A., Kelley, J.M., Kokkotou, E., Kaptchuk, T.J., 2012. Catechol-O-methyltransferase $\mathrm{val}^{158}$ met polymorphism predicts placebo effect in irritable bowel syndrome. PLoS One 7 , e48135.

Hannula, H., Neuvonen, T., Savolainen, P., Hiltunen, J., Ma, Y.Y., Antila, H., Salonen, O., Carlson, S., Pertovaara, A., 2010. Increasing top-down suppression from prefrontal cortex facilitates tactile working memory. NeuroImage 49, 1091-1098.

Hietala, J., Syvälahti, E., Vuorio, K., Någren, K., Lehikoinen, P., Ruotsalainen, U., Räkköläinen, V., Lehtinen, V., Wegelius, U., 1994. Striatal $\mathrm{D}_{2}$ dopamine receptor characteristics in neuroleptic-naive schizophrenic patients studied with positron emission tomography. Arch. Gen. Psychiatry 51, 116-123.

Hirvonen, J., Tuominen, L., Någren, K., Hietala, J., 2015. Neuroticism and serotonin 5$\mathrm{HT}_{1 \mathrm{~A}}$ receptors in healthy subjects. Psychiatry Res. 234, 1-6.

Hirvonen, M., Laakso, A., Någren, K., Rinne, J.O., Pohjalainen, T., Hietala, J., 2004. C957T polymorphism of the dopamine $\mathrm{D}_{2}$ receptor (DRD2) gene affects striatal DRD2 availability in vivo. Mol. Psychiatry 9, 1060-1061 (erratum in: Mol. Psychiatry 2005;10:889).

Hirvonen, M.M., Laakso, A., Någren, K., Rinne, J.O., Pohjalainen, T., Hietala, J., 2009. C957T polymorphism of dopamine $\mathrm{D}_{2}$ receptor gene affects striatal DRD2 in vivo availability by changing the receptor affinity. Synapse 63, 907-912.

Jääskeläinen, S., Rinne, J.O., Forssell, H., Tenovuo, O., Kaasinen, V., Sonninen, P., Bergman, J., 2001. Role of the dopaminergic system in chronic pain - A fluorodopaPET-study. Pain 90, 257-260.

Jääskeläinen, S.K., 2012. Pathophysiology of primary burning mouth syndrome. Clin. Neurophysiol. 123, 71-77.

Jääskeläinen, S.K., 2018. Is burning mouth syndrome a neuropathic pain condition? Pain 159, 610-613.

Jääskeläinen, S.K., Woda, A., 2017. Burning mouth syndrome. Cephalalgia 37, 627-647.

Jääskeläinen, S.K., Forssell, H., Tenovuo, O., 1997. Abnormalities of the blink reflex in burning mouth syndrome. Pain 73, 455-460.

Jääskeläinen, S.K., Lindholm, P., Valmunen, T., Pesonen, U., Taiminen, T., Virtanen, A., Lamusuo, S., Forssell, H., Hagelberg, N., Hietala, J., Pertovaara, A., 2014. Variation in the dopamine $\mathrm{D}_{2}$ receptor gene plays a key role in human pain and its modulation by transcranial magnetic stimulation. Pain 155, 2180-2187.

Jarcho, J.M., Feier, N.A., Labus, J.S., Naliboff, B., Smith, S.R., Hong, J.Y., Colloca, L., Tillisch, K., Mandelkern, M.A., Mayer, E.A., London, E.D., 2015. Placebo analgesia: self-report measures and preliminary evidence of cortical dopamine release associated with placebo response. Neuroimage Clin. 10, 107-114.

Kupers, R., Frokjaer, V.G., Naert, A., Christensen, R., Budtz-Joergensen, E., Kehlet, H., Knudsen, G.M., 2009. A PET $\left[{ }^{18} \mathrm{~F}\right]$ altanserin study of $5-\mathrm{HT}_{2 \mathrm{~A}}$ receptor binding in the human brain and responses to painful heat stimulation. NeuroImage 44, 1001-1007.

Kupers, R., Frokjaer, V.G., Erritzoe, D., Naert, A., Budtz-Joergensen, E., Nielsen, F.A., Kehlet, H., Knudsen, G.M., 2011. Serotonin transporter binding in the hypothalamus correlates negatively with tonic heat pain ratings in healthy subjects: a $\left[{ }^{11} \mathrm{C}\right] \mathrm{DASB}$
PET study. NeuroImage 54, 1336-1343.

Lacivita, E., Di Pilato, P., De Giorgio, P., Colabufo, N.A., Berardi, F., Perrone, R., Leopoldo, M., 2012. The therapeutic potential of 5- $\mathrm{HT}_{1 \mathrm{~A}}$ receptors: a patent review. Expert Opin. Ther. Pat. 22, 887-902.

Lamusuo, S., Hirvonen, J., Lindholm, P., Martikainen, I.K., Hagelberg, N., Parkkola, R., Taiminen, T., Hietala, J., Helin, S., Virtanen, A., Pertovaara, A., Jääskeläinen, S.K., 2017. Neurotransmitters behind pain relief with transcranial magnetic stimulation positron emission tomography evidence for release of endogenous opioids. Eur. J. Pain 21, 1505-1515.

Laruelle, M., 2000. Imaging synaptic transmission with in vivo binding competition techniques: a critical review. J. Cereb. Blood Flow. Metab. 20, 423-451.

Ledermann, K., Jenewein, J., Sprott, H., Hasler, G., Schnyder, U., Warnock, G., Johayem, A., Kollias, S., Buck, A., Martin-Soelch, C., 2016. Relation of dopamine receptor 2 binding to pain perception in female fibromyalgia patients with and without depression-A $\left[{ }^{11} \mathrm{C}\right]$ raclopride PET-study. Eur. Neuropsychopharmacol. 26, 320-330.

Lundkvist, C., Sandell, J., Någren, K., Pike, V.W., Halldin, C., 1998. Improved synthesis of the PET radioligands, $\left[{ }^{11} \mathrm{C}\right] \mathrm{FLB} 457,\left[{ }^{11} \mathrm{C}\right] \mathrm{MDL} 100907$ and $\left[{ }^{11} \mathrm{C}\right] \mathrm{b}-\mathrm{CIT}-\mathrm{FE}$, by the use of $\left[{ }^{11} \mathrm{C}\right]$ methyl triflate. J. Label. Compd. Radiopharm. 41, 545-556.

Maarrawi, J., Peyron, R., Mertens, P., Costes, N., Magnin, M., Sindou, M., Laurent, B., Garcia-Larrea, L., 2007. Motor cortex stimulation for pain control induces changes in the endogenous opioid system. Neurology 69, 827-834.

Magnusson, J.E., Fisher, K., 2000. The involvement of dopamine in nociception: the role of $D_{1}$ and $D_{2}$ receptors in the dorsolateral striatum. Brain Res. 855, 260-266.

Martikainen, I.K., Hagelberg, N., Mansikka, H., Hietala, J., Någren, K., Scheinin, H., Pertovaara, A., 2005. Association of striatal dopamine $D_{2} / D_{3}$ receptor binding potential with pain but not tactile sensitivity or placebo analgesia. Neurosci. Lett. 376, 149-153.

Martikainen, I.K., Hirvonen, J., Kajander, J., Hagelberg, N., Mansikka, H., Någren, K., Hietala, J., Pertovaara, A., 2007. Correlation of human cold pressor pain responses with 5-HT 1 A receptor binding in the brain. Brain Res. 1172, 21-31.

Martikainen, I.K., Hirvonen, J., Pesonen, U., Hagelberg, N., Laurikainen, H., Tuikkala, H., Kajander, J., Någren, K., Hietala, J., Pertovaara, A., 2009. Differential associations between brain $5-\mathrm{HT}_{1 \mathrm{~A}}$ receptor binding and response to pain versus touch. J. Neural Transm. (Vienna) 116, 21-30.

Martikainen, I.K., Nuechterlein, E.B., Peciña, M., Love, T.M., Cummiford, C.M., Green, C.R., Stohler, C.S., Zubieta, J.K., 2015. Chronic back pain is associated with alterations in dopamine neurotransmission in the ventral striatum. J. Neurosci. 35, 9957-9965.

McHaffie, J.G., Stanford, T.R., Stein, B.E., Coizet, V., Redgrave, P., 2005. Subcortical loops through the basal ganglia. Trends Neurosci. 28, 401-407.

Mico, J.A., Berrocoso, E., Ortega-Alvaro, A., Gibert-Rahola, J., Rojas-Corrales, M.O., 2006. The role of $5-\mathrm{HT}_{1 \mathrm{~A}}$ receptors in research strategy for extensive pain treatment. Curr. Top. Med. Chem. 6, 1997-2003.

Millan, M.J., 2002. Descending control of pain. Prog. Neurobiol. 66, 355-474.

Moisset, X., de Andrade, D.C., Bouhassira, D., 2016. From pulses to pain relief: an update on the mechanisms of rTMS-induced analgesic effects. Eur. J. Pain 20, 689-700.

Nakai, A., Kumakura, Y., Boivin, M., Rosa, P., Diksic, M., D'Souza, D., Kersey, K., 2003. Sex differences of brain serotonin synthesis in patients with irritable bowel syndrome using alpha- $\left[{ }^{11} \mathrm{C}\right]$ methyl-L-tryptophan, positron emission tomography and statistical parametric mapping. Can. J. Gastroenterol. 17, 191-196.

Niccolini, F., Su, P., Politis, M., 2014. Dopamine receptor mapping with PET imaging in Parkinson's disease. J. Neurol. 261, 2251-2263.

Ohnishi, T., Hayashi, T., Okabe, S., Nonaka, I., Matsuda, H., Iida, H., Imabayashi, E., Watabe, H., Miyake, Y., Ogawa, M., Teramoto, N., Ohta, Y., Ejima, N., Sawada, T., Ugawa, Y., 2004. Endogenous dopamine release induced by repetitive transcranial magnetic stimulation over the primary motor cortex: an $\left[{ }^{11} \mathrm{C}\right]$ raclopride positron emission tomography study in anesthetized macaque monkeys. Biol. Psychiatry 55, 484-489.

Peciña, M., Zubieta, J.K., 2015. Molecular mechanism of placebo responses in humans. Mol. Psychiatry 20, 416-423.

Peciña, M., Martinez-Jauand, M., Love, T., Heffernan, J., Montoya, P., Hodgkinson, C., Stohler, C.S., Goldman, D., Zubieta, J.K., 2014. Valence-specific effects of BDNF $\mathrm{Val}^{66} \mathrm{Met}$ polymorphism on dopaminergic stress and reward processing in humans. J. Neurosci. 34, 5874-5881.

Pertovaara, A., Martikainen, I.K., Hagelberg, N., Mansikka, H., Någren, K., Hietala, J., Scheinin, H., 2004. Striatal dopamine $\mathrm{D}_{2} / \mathrm{D}_{3}$ receptor availability correlates with individual response characteristics to pain. Eur. J. Neurosci. 20, 1587-1592.

Pike, V.W., McCarron, J.A., Lammertsma, A.A., Osman, S., Hume, S.P., Sargent, P.A., Bench, C.J., Cliffe, I.A., Fletcher, A., Grasby, P.M., 1996. Exquisite delineation of 5 $\mathrm{HT}_{1 \mathrm{~A}}$ receptors in human brain with PET and [carbonyl- ${ }^{11} \mathrm{C}$ ]WAY-100635. Eur. J. Pharmacol. 301, R5-R7.

Pinborg, L.H., Adams, K.H., Svarer, C., Holm, S., Hasselbalch, S.G., Haugbøl, S., Madsen, J., Knudsen, G.M., 2003. Quantification of 5- $\mathrm{HT}_{2 \mathrm{~A}}$ receptors in the human brain using $\left[{ }^{18} \mathrm{~F}\right]$ altanserin-PET and the bolus/infusion approach. J. Cereb. Blood Flow. Metab. 23, 985-996.

Rabiner, E.A., Messa, C., Sargent, P.A., Husted-Kjaer, K., Montgomery, A., Lawrence, A.D. Bench, C.J., Gunn, R.N., Cowen, P., Grasby, P.M., 2002. A database of $\left[{ }^{11} \mathrm{C}\right]$ WAY100635 binding to $5-\mathrm{HT}_{1 \mathrm{~A}}$ receptors in normal male volunteers: normative data and relationship to methodological, demographic, physiological, and behavioral variables. NeuroImage 15, 620-632.

Rogawski, M.A., Aghajanian, G.K., 1981. Serotonin autoreceptors on dorsal raphe neurons: structure-activity relationships of tyramine analogs. J. Neurosci. 1, 1148-1154.

Ruottinen, H.M., Partinen, M., Hublin, C., Bergman, J., Haaparanta, M., Solin, O., Rinne, J.O., 2000. An FDOPA PET study in patients with periodic limb movement disorder and restless legs syndrome. Neurology 54, 502-504.

Russell, I.J., Bieber, C.S., 2006. Myofascial pain and fibromyalgia syndrome. In: 
McMahon, S.B., Koltzenburg, M. (Eds.), Wall and Melzacks's Textbook of Pain, fifth ed. Elsevier, China, pp. 669-681.

Sakai, Y., Dobson, C., Diksic, M., Aubé, M., Hamel, E., 2008. Sumatriptan normalizes the migraine attack-related increase in brain serotonin synthesis. Neurology 70 , 431-439.

Savitz, J., Lucki, I., Drevets, W.C., 2009. 5- $\mathrm{HT}_{1 \mathrm{~A}}$ receptor function in major depressive disorder. Prog. Neurobiol. 88, 17-31. https://doi.org/10.1016/j.pneurobio.2009.01. 009.

Scott, D.J., Heitzeg, M.M., Koeppe, R.A., Stohler, C.S., Zubieta, J.K., 2006. Variations in the human pain stress experience mediated by ventral and dorsal basal ganglia dopamine activity. J. Neurosci. 26, 10789-10795.

Scott, D.J., Stohler, C.S., Koeppe, R.A., Zubieta, J.K., 2007a. Time-course of change in $\left[{ }^{11} \mathrm{C}\right]$ carfentanil and $\left[{ }^{11} \mathrm{C}\right]$ raclopride binding potential after a nonpharmacological challenge. Synapse 61, 707-714.

Scott, D.J., Stohler, C.S., Egnatuk, C.M., Wang, H., Koeppe, R.A., Zubieta, J.K., 2007b. Individual differences in reward responding explain placebo-induced expectations and effects. Neuron 55, 325-336.

Scott, D.J., Stohler, C.S., Egnatuk, C.M., Wang, H., Koeppe, R.A., Zubieta, J.K., 2008. Placebo and nocebo effects are defined by opposite opioid and dopaminergic responses. Arch. Gen. Psychiatry 65, 220-231.

Skyt, I., Moslemi, K., Baastrup, C., Grosen, K., Benedetti, F., Petersen, G.L., Price, D.D., Hall, K.T., Kaptchuk, T.J., Svensson, P., Jensen, T.S., Vase, L., 2018. Dopaminergic tone does not influence pain levels during placebo interventions in patients with chronic neuropathic pain. Pain 159, 261-272.

Stiasny-Kolster, K., Pfau, D.B., Oertel, W.H., Treede, R.D., Magerl, W., 2013. Hyperalgesia and functional sensory loss in restless legs syndrome. Pain 154, 1457-1463.

Strafella, A.P., Paus, T., Barrett, J., Dagher, A., 2001. Repetitive transcranial magnetic stimulation of the human prefrontal cortex induces dopamine release in the caudate nucleus. J. Neurosci. 21, RC157.

Strafella, A.P., Paus, T., Fraraccio, M., Dagher, A., 2003. Striatal dopamine release induced by repetitive transcranial magnetic stimulation of the human motor cortex. Brain 126, 2609-2615.

Swets, J.A., 1973. The relative operating characteristic in psychology: a technique for isolating effects of response bias finds wide use in the study of perception and cognition. Science 182, 990-1000.

Taniguchi, W., Nakatsuka, T., Miyazaki, N., Yamada, H., Takeda, D., Fujita, T., Kumamoto, E., Yoshida, M., 2011. In vivo patch-clamp analysis of dopaminergic antinociceptive actions on substantia gelatinosa neurons in the spinal cord. Pain 152,
95-105.

Taylor, B.K., Joshi, C., Uppal, H., 2003. Stimulation of dopamine $\mathrm{D}_{2}$ receptors in the nucleus accumbens inhibits inflammatory pain. Brain Res. 987, 135-143.

Tohyama, M., Takatsuji, K., 1998. Atlas of neuroactive substances and their receptors in the rat. Oxford Univ. Press, Oxford.

Tominaga, K., Tsumoto, C., Ataka, S., Mizuno, K., Takahashi, K., Yamagami, H., Tanigawa, T., Kawabe, J., Watanabe, T., Fujiwara, Y., Shiomi, S., Watanabe, Y., Arakawa, T., 2015. Regional brain disorders of serotonin neurotransmission are associated with functional dyspepsia. Life Sci. 137, 150-157.

Treister, R., Pud, D., Ebstein, R.P., Laiba, E., Gershon, E., Haddad, M., Eisenberg, E., 2009. Associations between polymorphisms in dopamine neurotransmitter pathway genes and pain response in healthy humans. Pain 147, 187-193.

Viisanen, H., Ansah, O.B., Pertovaara, A., 2012. The role of the dopamine $\mathrm{D}_{2}$ receptor in descending control of pain induced by motor cortex stimulation in the neuropathic rat. Brain Res. Bull. 89, 133-143.

Wei, H., Pertovaara, A., 2006. 5- $\mathrm{HT}_{1 \mathrm{~A}}$ receptors in endogenous regulation of neuropathic hypersensitivity in the rat. Eur. J. Pharmacol. 535, 157-165.

Wood, P.B., 2008. Role of central dopamine in pain and analgesia. Expert Rev. Neurother. 8, 781-797.

Wood, P.B., Patterson 2nd, J.C., Sunderland, J.J., Tainter, K.H., Glabus, M.F., Lilien, D.L., 2007a. Reduced presynaptic dopamine activity in fibromyalgia syndrome demonstrated with positron emission tomography: a pilot study. J. Pain 8, 51-58.

Wood, P.B., Schweinhardt, P., Jaeger, E., Dagher, A., Hakyemez, H., Rabiner, E.A., Bushnell, M.C., Chizh, B.A., 2007b. Fibromyalgia patients show an abnormal dopamine response to pain. Eur. J. Neurosci. 25, 3576-3582.

Wrobel, N., Wiech, K., Forkmann, K., Ritter, C., Bingel, U., 2014. Haloperidol blocks dorsal striatum activity but not analgesia in a placebo paradigm. Cortex 57, 60-73.

Yavich, L., Forsberg, M.M., Karayiorgou, M., Gogos, J.A., Männistö, P.T., 2007. Sitespecific role of catechol-O-methyltransferase in dopamine overflow within prefrontal cortex and dorsal striatum. J. Neurosci. 27, 10196-10209.

Yu, R., Gollub, R.L., Vangel, M., Kaptchuk, T., Smoller, J.W., Kong, J., 2014. Placebo analgesia and reward processing: integrating genetics, personality, and intrinsic brain activity. Hum. Brain Mapp. 35, 4583-4593.

Zhang, G., Stackman Jr., R.W., 2015. The role of serotonin 5-HT 2 A receptors in memory and cognition. Front. Pharmacol. 6, 225.

Zhu, M., Li, M., Ye, D., Jiang, W., Lei, T., Shu, K., 2016. Sensory symptoms in Parkinson's disease: clinical features, pathophysiology, and treatment. J. Neurosci. Res. 94, 685-692. 